University of Maryland Francis King Carey School of Law

DigitalCommons@UM Carey Law

\title{
The Constitutional Development of the Nineteenth Amendment in the Decade Following Ratification
}

\author{
Paula A. Monopoli \\ University of Maryland School of Law, pmonopoli@law.umaryland.edu
}

Follow this and additional works at: https://digitalcommons.law.umaryland.edu/fac_pubs

Part of the Constitutional Law Commons, Law and Gender Commons, and the Legal History Commons

\section{Digital Commons Citation}

Monopoli, Paula A., "The Constitutional Development of the Nineteenth Amendment in the Decade Following Ratification" (2019). Faculty Scholarship. 1631.

https://digitalcommons.law.umaryland.edu/fac_pubs/1631

This Article is brought to you for free and open access by the Francis King Carey School of Law Faculty at DigitalCommons@UM Carey Law. It has been accepted for inclusion in Faculty Scholarship by an authorized administrator of DigitalCommons@UM Carey Law. For more information, please contact smccarty@law.umaryland.edu. 


\title{
SYMPOSIUM: THE 19 ${ }^{\text {TH }}$ AMENDMENT AT 100: FROM THE VOTE TO GENDER EQUALITY
}

\section{The Constitutional DeVelopment of THE NINETEENTH AMENDMENT IN THE DECADE FOLLOWING RATIFICATION}

\begin{abstract}
Paula A. Monopoli*
As we gather at the Center for Constitutional Law's Symposium, The Nineteenth Amendment at 100: From the Vote to Gender Equality, I am struck by the recurring themes around American women and their government. ${ }^{1}$ Recently, the media has focused on the rift between the first female Speaker of the House of Representatives, Nancy Pelosi, and new member, Representative Alexandria Ocasio-Cortez. This division is reminiscent of the generational split in the suffrage movement between Carrie Chapman Catt and Alice Paul—a split that I would argue helps us understand the limited constitutional development of the Nineteenth Amendment in the decade following its ratification.

Like Pelosi, Catt was the older of the two women and more strategically and tactically conservative than the younger suffragist, Paul. Trained in the more radical tactics of the British Women's Social and Political Union, Paul was impatient with the elder Catt's focus on a stateby-state strategy for winning suffrage. Like Ocasio-Cortez has done visa-vis Pelosi, Paul engaged Catt directly, pushing the National American

* Sol \& Carlyn Hubert Professor of Law, University of Maryland Carey School of Law. Visiting Scholar, Moller Institute, Churchill College, University of Cambridge. The author's scholarship on the intersection of gender and the Constitution includes CONSTITUTIONAL ORPHAN: GENDER EQUALITY AND THE NINETEENTH AMENDMENT (forthcoming 2020) from Oxford University Press and Gender and Constitutional Design, 115 YALE L. J. 2643 (2006) reprinted in GENDER AND Constitutional Law (C. MacKinnon ed. 2018). The author would like to thank Reva Siegel, Tracy Thomas, Elizabeth Katz and the other symposium participants for their thoughtful comments. She would also like to thank Susan G. McCarty and Matthew A. Brown for their editorial assistance with this paper.

1. "The right of citizens of the United States to vote shall not be denied or abridged by the United States or by any State on account of sex. Congress shall have power to enforce this article by appropriate legislation.” U.S. CONST. amend. XIX.
\end{abstract}


Woman Suffrage Association (NAWSA) to embrace a more radical position. In Paul's case, that position was that a federal amendment was the right way to the ballot and that civil disobedience was an appropriate tactic to achieve that result. Paul subsequently broke with NAWSA to form the National Woman's Party (NWP). And, much as Catt finally had to move toward Paul's position and support the federal amendment, Pelosi has recently had to move toward Ocasio-Cortez's position to hold a formal impeachment inquiry. ${ }^{2}$

We also see echoes of the suffrage movement in the racism and xenophobia currently being weaponized against women exercising political power. The same antagonism toward immigrants and African Americans that animated much of the discourse around women votingwith some suffragists exploiting that fear and arguing that white women's votes would be useful in cancelling out those of uneducated immigrants and black voters-is still deployed for political purposes today. And women raising their voices in the public sphere still trigger visceral male reactions, as did the early suffragists who dared lecture in public and picket the White House during a time of war. In July 2019, the President of the United States attacked four Congresswomen on Twitter, all of whom were women of color. He suggested the representatives were nonnative born and should "go back and help fix the totally broken and crime infested places from which they came."3 This extreme and unfounded attack reminds us that when women dare to exercise political power, they still face the same threatening pushback visited on suffragists organizing and protesting for the vote prior to 1920. Finally, recent debates about whether those four Congresswomen are socialists evoke the attacks

2. Stefan Becket et al., Pelosi Launches Formal Trump Impeachment Inquiry, CBS NEWs, (Sept. 25, 2019, 1:41 PM), https://www.cbsnews.com/live-news/trump-impeachment-pelosilaunches-formal-impeachment-inquiry-of-president-donald-trump-wednesday/

[https://perma.cc/RK2C-6465] ("Speaker Nancy Pelosi announced the House is launching a formal impeachment inquiry into President Trump.... The speaker has long resisted calls from many progressive lawmakers to initiate impeachment proceedings against the president, but Democrats appear to have reached a breaking point ....”)

3. Devan Cole, Trump Tweets Racist Attacks at Progressive Democratic Congresswomen, CNN (July 14, 2019, 8:32 PM), https://www.cnn.com/2019/07/14/politics/donald-trump-tweetsdemocratic-congresswomen-race-nationalities/index.html [https://perma.cc/ADS4-9BWE] ("President Donald Trump used racist language on Sunday to attack progressive Democratic congresswomen, falsely implying they weren't natural-born American citizens. Trump did not name who he was attacking in Sunday's tirade but earlier this week he referenced New York Rep. Alexandria Ocasio-Cortez when the President was defending House Speaker Nancy Pelosi. A group of Democrats, who are women of color and have been outspoken about Trump's immigration policies, last week condemned the conditions of border detention facilities. The group of women joining Ocasio-Cortez were Rashida Tlaib of Michigan, Ilhan Omar of Minnesota and Ayanna Pressley of Massachusetts.”). 
endured by suffragists, who were maligned as socialists and atheists. ${ }^{4}$ So there is much work left to be done.

The Nineteenth Amendment represented a significant moment in American history that held promise for changing the narrative around women exercising political power. But as we can see from contemporary politics, many of the same themes continue. So as part of our celebration of its Centennial, we should ask why the Nineteenth did not have more impact on the civil, political, and social status of women in our republic. The post-ratification story of the Nineteenth involved philosophical issues like the relationship between the individual and the state. It also implicated constitutional issues, including federalism, the scope of woman's citizenship and the constitutional meaning of equality. And it was shaped by the intersection of race, gender and class.

My forthcoming book from Oxford University Press, Constitutional Orphan: Gender Equality and the Nineteenth Amendment, offers an account of the constitutional development of the Nineteenth Amendment in the decade following its ratification in 1920. It examines how a thin conception of the Nineteenth emerged, and the role suffragists played in that story. In so doing, the book illuminates a piece of the puzzle as to why the Nineteenth had so little impact on women's broader political, social and legal status as citizens.

It was predictable that the implementation of an amendment expanding women's power in a society structured around their legal, social and economic subordination would meet with substantial resistance. As institutional actors, Congress, state legislatures and the federal and state courts all held the power to implement the Nineteenth in a narrow or "thin" way or to give it a more robust or "thick" constitutional meaning. And each played a significant role in the thin constitutional conception of the Nineteenth that emerged by the end of the decade after its ratification.

While Congress and the courts are significant sites of constitutional interpretation, social movements within civil society play important roles as well. Through their efforts to enfranchise American women, suffragists assumed such a role. Although they were not as powerful as other institutional actors, I argue that strategic choices made by suffragists in the wake of ratification also played a role in the limited development of the Nineteenth. The meaning of the Nineteenth was contested in the

4. Liz Harrington, The Socialist "Squad" Does Not Like America: Take it From Them, https://townhall.com/columnists/lizharrington/2019/07/21/the-socialist-squad-does-not-likeamerica-take-it-from-them-n2550365 [https://perma.cc/DTE7-8VSZ]. 
decade after ratification. But the national suffrage organizations that had been instrumental in its enactment did not keep up a unified, sustained pressure on either Congress or the courts to resolve that process in favor of an expansive understanding of the Amendment. The promise that courts might interpret the Nineteenth as having an impact beyond voting was little realized, and it became a constitutional orphan, rarely cited after $1930 .^{5}$

The book's chapters lay out a brief history of the suffrage movement in the last years prior to ratification. ${ }^{6}$ They describe the immediate pivot of the NWP from the Nineteenth to the Equal Rights Amendment in 1921. There was a parallel mission-shift by NAWSA. In 1920, it became the National League of Women Voters (NLWV) and embraced social welfare legislation and voter education as its primary goals. As noted above, that shift in mission by both organizations accounts for the lack of a unified presence as questions arose in state courts about the meaning of the Nineteenth and in Congress about whether enforcement legislation was necessary.

The suffragists' choice to shift goals did not mean that they were absent from sites of potential constitutional interpretation and enforcement, like Congress and state legislatures. They were doing other work in those sites, lobbying for the reform of discriminatory state laws and for the proposed Equal Rights Amendment or social welfare legislation. Much of that work inured to the benefit of women. So my goal is not to suggest that the choices they made did not improve the lives of American women and move us closer to gender equality. They did. The NWP was instrumental in the introduction of six hundred bills in state legislatures aimed at striking down laws discriminating against women, three hundred of which were enacted. And the NLWV supported passage

5. "Even though the quest for the vote spanned generations and provoked the most sustained dialogue about women's position in the constitutional community that the nation has ever conducted, the Nineteenth Amendment has been utterly excluded from the constitutional canon.” Reva B. Siegel, She the People: The Nineteenth Amendment, Sex Equality, Federalism, and the Family, 115 HARV. L. REV. 947, 950 (2002) [hereinafter She the People].

6. Paula Monopoli, Constitutional ORPhan: Gender Equality and the NinETEENTH AMENDMENT ch. 1, (Ratification) (forthcoming 2020). Professor Tracy Thomas gave a comprehensive summary of the intellectual and political history of the full seventy-two year woman's suffrage movement in her symposium presentation. Tracy Thomas, University of Akron School of Law, Address at The 19th Amendment at 100: From the Vote to Gender Equality: More Than the Vote: From Seneca Falls to ERA (Sept. 20, 2019). For that full seventy-two year history, see also, Tracy A. Thomas, More Than the Vote: The Nineteenth Amendment as Proxy for Gender Equality, Stan. J. Civ. RTS. \& Civ. LiBerties (forthcoming 2019) (manuscript at 5-8), https://www.uakron.edu/law/ccl/docs/19th-amend-conf-cle-materials.pdf [https://perma.cc/QY6XV3V9]. 
of social welfare legislation like the Sheppard-Towner Act, a bill providing federal funds for better maternal and infant health. Rather, I suggest that by examining their strategic choices, we can better understand the under-development of the Nineteenth as an alternative tool for gender equality and women's equal citizenship.

The pervasive effect of white southerners' concerns about states' rights and their fear of giving African American women the vote, also played a pivotal role in truncating the effect of the Nineteenth. As always, race, gender and class have a significant impact on how law develops. The Nineteenth Amendment was no different, with race and the legacy of the Civil War playing a central role in its constitutional development. Southern resistance to giving women the vote was, in large part, connected to the fear of a "Second Reconstruction" and the specter of enforcement legislation, akin to that passed and implemented in the wake of ratification of the Fourteenth and Fifteenth Amendments. ${ }^{7}$ My book documents the initially strong, and later minimal, at best, effort by suffrage organizations to support the passage of Congressional enforcement legislation, which was introduced pursuant to the section two of the Nineteenth but which was never enacted. ${ }^{8}$ Those groups also chose not to join the efforts of African American suffrage leaders like Ida B. Wells-Barnett and Mary Church Terrell, the National Association of Colored Women's Clubs (NACWC) and the National Association for the Advancement of Colored People (NAACP) in responding to voter suppression in the South with litigation and legislation. This reluctance to support enforcement legislation and judicial challenges to voter suppression was fueled, in part, by racism. But it was also fueled by the NWP's perception that it needed white southern support for its new federal amendment - the Equal Rights Amendment. And that it needed similar support for state legislation that removed the legal disabilities of women.

The leadership of the NWP included a number of experienced women lawyers like Florence Kelley, general secretary of the National Consumers League (NCL). Kelley had deep roots in strategic, test-case litigation, like Muller v. Oregon, which upheld protective legislation for

7. In her symposium presentation, The Nineteenth Amendment: The Fourth Civil War Amendment, Professor Kimberly Hamlin also discussed the role that white southern concerns around the Fifteenth Amendment played before enactment of the Nineteenth Amendment. Kimberly Hamlin, Miami University, Address at The 19th Amendment at 100: From the Vote to Gender Equality: The 19th Amendment: The Fourth Civil War Amendment? (Sept. 20, 2019). See also, KimBERLY HAMLIN, Free Thinker: Helen Hamilton Gardener's Radical PURSUIT OF Equality and the Vote (forthcoming 2020).

8. MonOPOLI, supra note 6, at ch. 3, (Enforcement Legislation). 
women workers. ${ }^{9}$ Both the NWP and NAWSA also had an extensive political infrastructure, developed over decades of successful lobbying of Congress and state legislatures. The NWP and NAWSA (through its successor, the NLWV) could have chosen to work more closely with the NACWC and the NAACP, whose founders include white NWP members like Kelley and Mary White Ovington. Such a unified effort could have focused on pushing enforcement legislation out of Congress and bringing cases under such legislation in federal courts, challenging state barriers to African American women voting. Even with such unified pressure, it is questionable whether Congress would have enacted enforcement legislation, given the political power of white southern politicians. But such a federal forum, created by enforcement legislation, might have produced the equivalent of a case like Strauder v. West Virginia or Neal $v$. State of Delaware which required states to allow newly enfranchised African American men to serve on juries under statutes enacted pursuant to the enforcement clauses of the Fourteenth and Fifteenth Amendments. ${ }^{10}$ Such cases would have created an opportunity for federal courts to consider Congressional intent in the context of the broad, antisubordination discourse around woman suffrage in the seventy-two years preceding ratification of the Nineteenth. While those courts may not have given the Nineteenth a thicker meaning than simply "a nondiscrimination rule governing voting," ${ }^{11}$ such federal litigation might have engendered

9. 208 U.S. 412, 423 (1908).

10. See, Strauder v. West Virginia, 100 U.S. 303 (1879) (in which the court reversed the decision of the West Virginia Supreme Court, holding that a state statute that only allowed white male persons to serve as jurors was unconstitutional under the Fourteenth Amendment's equal protection clause and affirming the power of Congress to enact enforcement legislation pursuant to the fifth clause of the Fourteenth. In dicta, the court unfortunately also stated that states could continue to exclude jurors based solely on sex.); Neal v. State of Delaware, 103 U.S. 370 (1880) (in which the court affirmed Strauder and invoked the Fifteenth Amendment as well as the Fourteenth.) In his dissent, Justice Field argues that the fifth clause of the Fourteenth did not give Congress the authority to enact, "the fourth section of the act of March 1, 1875, c. 114" providing that no citizen should be denied the right to serve on a jury due to race, color and previous condition of servitude. Id. at 404405. In analyzing Strauder, Professor Steven Calabresi and Attorney Julia Rickert note that, while "[t]he U.S. Supreme Court has never drawn a connection between the right to vote and the right to serve on a jury," some scholars have suggested it would be "senseless" to conclude that the Constitution protected the most important political right-voting-but did not protect a lesser political right like jury service. See Steven G. Calabresi and Julia T. Rickert, Originalism and Sex Discrimination, 90 TEXAS L. REV. 1, 77-78 (2011) (proposing an original public meaning interpretive approach to the Nineteenth Amendment.) There was no similar federal enforcement legislation pursuant to section two of the Nineteenth, which could have ensured a uniform conclusion by all state courts that considered the question of whether voting was co-extensive with jury service.

11. This is the way Professor Reva Siegel describes the thin conception of the Nineteenth that emerged by the end of the decade following ratification. Siegel, She the People, supra note 5, at 101922. 
more judicial consideration of the relationship between the Nineteenth, the Fourteenth and the Fifteenth Amendments. This, in turn, would have provided more extensive judicial insight with which to reason about the civil, political and legal rights of women going forward.

While suffragist advocacy around the Nineteenth slowed substantially after ratification, the cascade of constitutional questions triggered by its ratification did not. The first of these questions was, as a matter of federalism, how much power did the national government have to dictate voter eligibility criteria? ${ }^{12}$ This issue was implicit in the pending Congressional enforcement legislation described above. It was also implicated in state cases that parsed the impact of a federal amendment on state law like the general taxing power. Determining the precise boundary lines between federal and state sovereignty in this area was at the center of the state litigation around pre-conditions to voting, like poll taxes, that followed ratification of the Nineteenth.

Federalism was also at the heart of cases which sought a determination of the impact of the Nineteenth on state laws that regulated political rights like jury service and holding public office. ${ }^{13}$ Federal constitutional amendments, constructed like the Nineteenth, were generally presumed to be "self-executing" as a constitutional matter and were seen as preemptive of contrary state legislation or constitutional provisions. But there were widely disparate state court approaches to construction of the Nineteenth. Some courts adopted an expansive view of the Nineteenth, deciding that rights like jury service were "coextensive" with voting. Perhaps fearing the broad social change the Nineteenth signaled in the role of women in the family, the market, and the constitutional community, or its political impact on state sovereignty, other courts cabined the federal impact of the Nineteenth on state law. ${ }^{14}$

12. See, e.g., Id. at 998-1003.

13. Professor Elizabeth Katz gave a comprehensive history of the public office cases, before ratification of the Nineteenth Amendment, in her symposium presentation. Elizabeth Katz, Washington University School of Law, Address at The Nineteenth Amendment at 100: From the Vote to Gender Equality: Women's Suffrage \& the Right to Hold Public Office (Sept. 20, 2019). See also, Elizabeth D. Katz, “A Woman Stumps Her State”: Nellie G. Robinson and Women's Right to Hold Public Office in Ohio, AKRON L. REV. (forthcoming 2020) (manuscript on file with author). Katz notes that, "the [Nineteenth] amendment itself did not conclusively settle the question of women's officeholding rights. Litigation and state constitutional amendments on this issue continued through the 1920s. But the amendment did provide the basis for eventually securing women's officeholding rights.” Id. at 34, n. 167.

14. In her presentation, Professor Reva Siegel discussed the historical evidence that the suffrage movement was heavily grounded in demands for changes in women's legal subordination within the family. Reva Siegel, Yale Law School, Address at The Nineteenth Amendment at 100: From the Vote to Gender Equality: The Nineteenth Amendment \& the Democratic Reconstruction of 
They adopted a constrictive interpretation of its meaning, declaring it narrowly applicable to the ballot only. As noted above, unlike the legislation enacted pursuant to the Fourteenth and the Fifteenth amendments, there was no federal enforcement legislation that forbid states from denying women the right to serve on juries or hold public office, based on their sex. ${ }^{15}$ Thus, state courts were left to their own construction of the scope of the Nineteenth on this question, untethered by any Congressional direction or constraints.

The second constitutional question raised by the Nineteenth was the scope of woman's citizenship under the federal Constitution. This question was inextricably intertwined with the question above about whether voting and jury service or voting and holding public office were coextensive. The same cases in which state judges parsed doctrines like the self-executing nature of constitutional amendments also demanded resolution of the question whether the Nineteenth went beyond simply voting and expanded women's political rights. ${ }^{16}$ In the realm of defining women's place in the constitutional order, judicial views about proper gender spheres undoubtedly drove some decisions about whether such rights were coextensive as a matter of statutory or constitutional interpretation. These decisions, in turn, often limited the expansion of women's civil and political rights other than voting. ${ }^{17}$ The result was a continuation of women's partialized citizenship for many decades after ratification of the Nineteenth Amendment.

Third, ratification of the Nineteenth implicated the definition of gender equality under the Constitution. In Adkins v. Children's Hospital, ${ }^{18}$

the Family: Recovering a Constitutional Tradition (Sept. 20, 2019). See also Reva B. Siegel, The Nineteenth Amendment and the Democratization of the Family, 129 YALE L.J.F. 450 (January 21, 2020). Siegel argues that, "The debate about women voting in the decades after the founding centrally concerned the family. A male head of household was enfranchised to represent his wife, children, and other members of the household. A woman's claim to vote was a challenge to this system of 'virtual representation,' and for this very reason, a claim for democratic reconstruction of the family." Id. at 452.

15. MonOPOLI, supra note 6, at ch. 3, (Enforcement Legislation).

16. Monopoli, supra note 6, at ch. 5 (Voting and Jury Service). Note that while jury service has sometimes been characterized as a civil right, scholars have argued it is more akin to a political right. See, Vikram David Amar, Jury Service as Political Participation Akin to Voting, 80 CORNELL L. REV. 203, 204 (1995).

17. See, e.g., State v. James, 114 A. 553 (N.J. Err. \& App. 1921) (holding the Nineteenth applied only to voting and did not extend to jury service). However, other states courts came to a different result on the same question, applying a less constricted and more expansive construction of the Nineteenth. See, e.g. People v. Barltz, 180 N.W. 423 (Mich. 1920) (holding the Nineteenth Amendment extends to jury service as well as voting.)

18. Adkins v. Children's Hospital, 261 U.S. 525 (1923), overruled in part by West Coast Hotel v. Parrish, 300 U.S. 379 (1937). 
the United States Supreme Court invoked the Nineteenth when grappling with the constitutionality of protective labor legislation that regulated wages for women, but not for men. ${ }^{19}$ This issue was informed not only by gender, but by class in the first decades of the twentieth century. Many professional and upper-class neutrality feminists ${ }^{20}$ tended to support formal equality and a laissez faire view of the relationship between the State and the individual. Such a view favored limitations on the government's power to intrude into spheres like the employer-employee relationship. These feminists saw protective legislation as a civil rights issue, in that such legislation limited a woman's liberty to contract for her labor. Alternatively, other upper-class social feminists and working class women tended to embrace government intervention in such relationships, supporting laws that required minimum wages and maximum hours. Judges embracing a laissez faire approach were more likely to find unconstitutional those governmental regulations that interfered with or limited an individual's right to negotiate a wage contract with an employer. ${ }^{21}$

Much of the debate between the neutrality feminists and the social feminists that followed ratification of the Nineteenth split along these lines. It was focused on the potential impact of the proposed Equal Rights Amendment on the validity of protective legislation. ${ }^{22}$ Today's courts are still grappling with how they should interpret statutes that protect against sex discrimination in the workplace, when the case involves differential

19. These cases involved challenges to protective legislation that required employers to abide by maximum hour and minimum wage legislation. The United States Supreme Court upheld a maximum hour law in Muller v. Oregon, 208 U.S. 412 (1908). However, in 1923 the Court distinguished a minimum wage law as unrelated to the physical differences between men and women that justified its decision in Muller. And it found such a minimum wage law unconstitutional. See Adkins, 261 U.S. 525.

20. I am using the term "neutrality feminist" to describe suffragists, like Alice Paul, who embraced the view that the Constitution should be interpreted to simply invalidate any "class legislation" that treated men and women differently in order to render equality. I use the term "social feminist" to describe feminists, like Florence Kelley, who believed that police power inherent in the Constitution to provide for the general health and welfare of the populace justified legislation that recognized the asymmetry of power based on both sex and class. Their position was that such legislation rendered equality of outcomes, a more substantive definition of constitutional equality.

21. See, e.g., Adkins, 261 U.S. 525, in which Justice Sutherland, a laissez-faire adherent who had advised Alice Paul on drafting the Equal Rights Amendment when he was a Senator, wrote the majority opinion striking down the District of Columbia's minimum wage law. See, Siegel, She the People, supra note 5 at 1014.

22. One way we might characterize the protective labor legislation cases, is as a debate about whether our Constitution merely guarantees a neutral or "formal” approach to equality, i.e., ensuring that women simply have the same opportunities as men. Or, whether our Constitution should be interpreted to ensure "substantive" equality—similar outcomes, taking into account differences between men and women. 
treatment based on pregnancy. These cases raise the question of whether courts should apply law as if men and women are the same (a neutrality view) or different (acknowledging that effectuating women's equality in the workplace may actually require different treatment of pregnant women.) ${ }^{23}$ This neutrality versus difference debate about the meaning of constitutional equality was at the heart of the battle for and against the Equal Rights Amendment. The neutrality feminists' battle with social feminists and legal progressives, who opposed the Equal Rights Amendment, distracted either side from more extensive involvement in the post-ratification development of the Nineteenth. ${ }^{24}$

We still have no federal Equal Rights Amendment today. If the former suffragists had made strategic choices that focused on more securely embedding the broad, anti-subordination norm of the Nineteenth Amendment in the federal and state legal fabric in the decade following its ratification, would later efforts to enact a new amendment and to build a constitutional jurisprudence of equality have come more quickly and have been more successful? Perhaps. But it is hard to know. Powerful actors like white southern politicians in Congress and state court judges who embraced strong state sovereignty views might still have succeeded in ensuring that a thin conception of the Nineteenth emerged. Those institutional actors who were concerned with the impact of a thicker meaning of the Nineteenth on the role of women in the family, the market and the political community would have resisted such an interpretation. But it was easier for those actors to do so without sustained pressure from the former suffragists to do otherwise.

In her seminal article She the People: The Nineteenth Amendment, Sex Equality, Federalism and the Family, Reva Siegel notes that, “[m]odern sex discrimination doctrine is built on this 'thin' conception of the Nineteenth Amendment-on the assumption that the Nineteenth Amendment is a nondiscrimination rule governing voting that has no bearing on questions of equal citizenship for women outside the franchise." 25 Siegel goes on to describe the United States Supreme Court's approach to sex discrimination doctrine as one that ignores the

23. See, e.g., Young v. United Parcel Service, Inc., 135 S. Ct. 1338 (2015) (interpreting the Pregnancy Discrimination Act amendments to Title VII of the Civil Rights Act of 1964). See, also, Deborah L. Brake, On Not Having It Both Ways and Still Losing: Reflections on Fifty Years of Pregnancy Litigation under Title VII, 95 B. U. L. REV. 995 (2015).

24. MonOPOLI, supra note 6, at ch. 7, (Defining Equality). Note that social feminists would have been wary of encouraging a robust view of the Nineteenth, at least as applied to protective legislation, given the Adkins Court's invocation of the Nineteenth in striking down a minimum wage statute for women.

25. Siegel, She the People, supra note 5, at 1022. 
constitutional history embodied in the debates leading up to ratification of the Nineteenth. ${ }^{26}$ She concludes that the Court's reliance on the Fourteenth Amendment alone signals a view that the source of constitutional law governing the scope of woman's citizenship is derived solely from an analogy to race. ${ }^{27}$ "These assumptions have given rise to a body of sex discrimination doctrine that is limited in legitimacy and acuity by the ahistorical manner in which it was derived from the law of race discrimination." 28

My book offers an account of how that thin conception of the Nineteenth arose. And within that account, I examine the role played by national suffrage organizations, as institutional actors, in that story. With Congress, state legislatures and state and federal courts important sources of constitutional enforcement and interpretation, the suffrage movement faced powerful patriarchal agents that were, as a matter of institutional self-interest, likely inclined to limit the impact of women's enfranchisement. ${ }^{29}$ Even if former suffragists had been more engaged in applying pressure to develop an expansive meaning of the Nineteenth, it is unlikely that a more robust interpretation would have emerged from such entrenched institutions, until it was expedient for them to embrace one. ${ }^{30}$ But the strategic choice made by the suffragists who secured final passage and ratification of the Nineteenth Amendment-to turn away from both lobbying for enforcement legislation and engaging in litigation that might have deepened its meaning as law-played a role in the thin conception that emerged in subsequent years.

As Vicki Schultz has pointed out in the context of Title VII, when activists stop advocating, at best, the law fails to develop and, at worst, it

26. Id.

27. Id. Siegel proposes a synthetic interpretation of the Fourteenth and the Nineteenth Amendments based on a sociohistoric reading of the suffrage amendment in American constitutional history. Id. at 949, 952.

28. Id. at 1022.

29. Jeannette Rankin (R-Montana) was the first woman elected to Congress and the only one to vote in 1918 on the text of the bill that later became the Nineteenth Amendment. See James J. Lopach and Jean A. Luckowski, JeAnNETte RANKin: A Political WomAn (2005) at 146.

30. For example, President Wilson arguably decided to support a federal suffrage amendment, after having been opposed to one, only when it became essential to his war effort to do so. See Neil S. Siegel, Why the Nineteenth Amendment Matters Today: A Guide for the Centennial, 27 DuKE J. OF GENDER L. \& POL'Y (forthcoming) (manuscript at 9-10) (available at https://ssrn.com/ abstract=3461919 [https://perma.cc/9FAX-DXZS]) (describing Wilson's shift from opponent to supporter of the federal suffrage amendment, suggesting reasons why he might have changed his position.); See, also, supra note 21, highlighting the connection between Alice Paul and Justice George Sutherland, whose robust view of the Nineteenth, as articulated in his opinion in Adkins, may be explained, in part, as a way to bolster his arguments for liberty of contract and substantive due process. 
develops in a counterproductive way: "In areas of law where feminists did not campaign to challenge difference, or where they later took a less decisive or divided stance as the women's movement began to fade and fracture, the absence of visible, unified feminist pressure permitted judges to retain or retreat back to older, biased views that attribute workplace inequality to women's own preferences." ${ }^{31}$ Schultz suggests that it is therefore important to examine, "not only the influence of a social movement overall, but also the rise of internal divisions within the movement and changes in its presence, visibility, and strength over time, in shaping legal developments." 32 Thus, the book also explores the postratification divisions between the neutrality feminists and the social feminists, and how those divisions shaped the constitutional development of the Nineteenth.

The book concludes by examining some of the ways that the Nineteenth could be used, either directly or synthetically with the Reconstruction Amendments, to reason differently about sex discrimination and women's equal citizenship in the realm of voting rights and beyond. ${ }^{33}$ Given the current uncertainty about the status of the

31. Vicki Schultz, Taking Sex Discrimination Seriously, 91 DENV. U. L. REV. 995, 1003 (2015).

32. Id. at 1003. Some scholars have argued that a similar lack of support from women's rights organizations for the private right of action under the Violence Against Women's Act (VAWA) was, in part, to blame for its eventual demise at the hands of the United States Supreme Court. See Caroline S. Schmidt, What Killed the Violence Against Women's Act Civil Rights Remedy Before the Supreme Court Did?, 101 VA. L. REv. 501, 530-33 (2015).

33. Monopoli, supra note 6, at ch. 8, (The Nineteenth Amendment Today). See also Siegel, The Nineteenth Amendment and the Democratization of the Family, supra note 14, at 482-489 for several "ways in which an institutional understanding of the Nineteenth Amendment can guide the Court's interpretation of the Equal Protection Clause" and citing Justice Ginsburg's majority opinion in United States v. Virginia, 518 U.S. 515 (1996) as one that "invite[s] synthetic interpretation." Id. at 484. See, also, Richard L. Hasen and Leah M. Litman, Thin and Thick Conceptions of the Nineteenth Amendment Right to Vote and Congress's Power to Enforce It, GEO. L. J. (forthcoming 2020) (manuscript at 20), https://papers.ssrn.com/sol3/papers.cfm?abstract_id=3501114 [https://perma.cc/3QLH-X625] (proposing "a litigation strategy premised on a revived Nineteenth Amendment within the scope of a cluster of new voting rights claims.") One potential direct application is to state laws that require the payment of fees and fines by those convicted of felonies prior to reinstatement of voting rights, barriers to voting which often have a disparate impact on women given the gender pay gap. In her inspiring keynote speech, Nancy Abudu, Deputy Legal Director and Voting Rights Director at the Southern Poverty Law Center described the current litigation around such a state statute in Florida. Nancy Abudu, Southern Poverty Law Center, Address at The Nineteenth Amendment at 100: From the Vote to Gender Equality: Voting Rights Today (Sept. 20, 2019). And Professor Michael Gentithes discussed the modern relevance of the Nineteenth Amendment to felony disenfranchisement in his symposium presentation. Michael Gentithes, University of Akron School of Law, Address at The Nineteenth Amendment at 100: From the Vote to Gender Equality: Felony Disenfranchisement and the Nineteenth Amendment (Sept. 20, 2019); Michael Gentithes, Felony Disenfranchisement \& The Nineteenth Amendment AKRON L. REV. 
proposed Equal Rights Amendment, revisiting the jurisprudential potential of the Nineteenth Amendment can shed light on how we may better secure women's constitutional equality today.

(forthcoming),

https://www.uakron.edu/law/ccl/docs/19th-amend-conf-cle-materials.pdf [https://perma.cc/QY6X-V3V9]. 